\title{
Mindsets of Leadership Education Undergraduates: An Approach to Program Assessment
}

\author{
Sarah P. Ho \\ Academic Advisor \& Ph.D. Student \\ Department of Agricultural Leadership, Education, \& Communications \\ 2116 TAMU \\ Texas A\&M University \\ College Station, TX 77843-2116 \\ spenaho@tamu.edu \\ Summer F. Odom \\ Assistant Professor \\ Department of Agricultural Leadership, Education, \& Communications \\ 2116 TAMU \\ Texas A\&M University \\ College Station, TX 77843-2116 \\ summerodom@tamu.edu
}

\begin{abstract}
Students $(N=313)$ in undergraduate leadership degree programs at Texas A\&M University were surveyed to determine their leadership mindset using hierarchical and systemic thinking preferences. Significant differences in thinking were found between gender and academic classification. Male leadership students scored greater in hierarchical thinking than females. Seniors, leadership students typically in their last semester of studies, scored significantly lower in hierarchical thinking than juniors. Findings indicate formal leadership coursework influences students' leadership mindsets.
\end{abstract}

\section{Introduction}

Leadership continues to be in high demand across many contexts today. Research shows that employers look for recent graduates who possess leadership and the associate skills such as communication, decision making, self-management, teamwork, professionalism, and experiences (Crawford, Lang, Fink, Dalton, \& Fielitz, 2011). Annually, the National Association of Colleges and Employers (NACE) completes a job outlook survey, and "employers are looking for team players who can solve problems, organize their work, and communicate effectively" (NACE, 2013, para. 1). In our evolving society, leadership is critical to organizing individuals to collaboratively solve serious problems (Allen, Stelzner, \& Wielkiewicz, 1998, Greenwald, 2010).

Defining leadership continues to be a complicated process resulting in a variety of definitions, attitudes, and perceptions. Even though the demand for leadership knowledge continues to grow, there is a lack of consensus in defining leadership and practicing leadership. Over the last several decades, leadership scholars have defined leadership in a variety of ways 
and have shifted their focus from just the leader to the relational process between leader and follower (Bass, 2008). Traditionalists view leadership as purely hierarchical and assigned, while progressives support a systems approach that relies on members to emerge and contribute to the organization's decisions (Northouse, 2013; Wielkiewicz, 2000).

In response to the increasing need of leadership skills and perspectives, leadership development has remained the focus in higher education. Colleges and institutions across the nation have incorporated leadership into their mission statements, have identified leadership as a core value, and have developed a variety of leadership training opportunities (Astin \& Astin, 2000). Others have developed unique leadership education programs for students to learn leadership principles through formal settings and practice their leadership skills through a variety of experiences (Brungardt, Greenleaf, Brungardt, \& Arensdorf, 2006).

While incorporating leadership education and development is deemed important for colleges and universities, teaching leadership and developing leadership curriculum has its challenges. In the editors' introduction of the summer 2009 edition of the Journal of Leadership Education, Middlebrooks and Allen embarked on a study of leadership education professional organizations. This study identified the biggest challenge facing leadership education as being able to clarify leadership complexity. This meant that leadership educators were concerned with being able to convince individuals that leadership is far more effective and has better long-term results if the process is conceived as more than just traits, position, and hierarchy of the leader. It was specifically noted that "helping students understand that leadership is not about formal authority and positions" and "conventional paradigms of leadership and 'cook-book' strategies distract us from learning the important lessons of leadership-deeper leadership" (Middlebrooks $\&$ Allen, 2009, p. xiii). This supports the study that employers prefer recent college graduates who can see the "big picture" and strategically think rather than the technical knowledge ranked by most faculty and students (Crawford, 2011). Likewise, NACE (2013) reported the skills of teamwork and problem solving as key factors for employability. Both calls reinforce the need for college graduates to think systemically - understanding the interdependent nature of leadership through team structures and critical thinking processes. To ensure colleges are meeting organizational needs, leadership educators must evaluate their courses and program design.

Goertzen (2009) asserted that leadership educators "must intentionally engage in conversations regarding sound student learning outcomes and measurement of student attainment" (p. 159). Leadership education and development programs continue to define their outcomes, determine core leadership courses, and create streamlined curricula based on assessments and evaluation of student leadership definitions, knowledge, attitudes, and practices. Haber (2012) found differences in leadership definitions by gender and age. Another study found that students' self-perceived practical leadership skills of problem definition, discovery of research alternatives, delegation/teamwork, and achievable challenge improved at the conclusion of a leadership development program (Blackwell, Cummins, Townsend, \& Cummings, 2007). Black and Earnest (2009) developed a summative method for participants at the conclusion of a leadership development program to determine the amount of knowledge retained and found positive improvements and self-perceived gains. 
Despite the focus on leadership education and development, little research exists on leadership mindsets or leadership thinking of undergraduate students as the result of leadership education programs and established curricula. Priority II of the National Leadership Education Research Agenda for the Association of Leadership Educators (Andenoro et al., 2013) articulated the need to evaluate leadership programs. To develop highly effective leadership education curricula, "programmatic monitoring and evaluation are critical for leadership educators to consider as they attempt to determine if their practice is achieving the desired outcomes" (Andenoro et al., 2013, p. 10). At Texas A\&M University, two undergraduate leadership degree programs exist in the Department of Agricultural Leadership, Education, and Communications: Agricultural Leadership and Development (ALED) and University Studies-Leadership Studies (USAL-LED). The degrees require students to progress through a systematic design of leadership coursework building on leadership from the individual perspective to leadership through a global lens. This study provided an opportunity to expand the existing research of leadership education students and collect data measuring the impact of leadership curriculum on individual student leadership mindsets or leadership thinking.

\section{Literature Review and Conceptual Framework}

Using a grounded theory approach, Komives, Owen, Longerbeam, Mainella, and Osteen (2005) developed a model for how college students develop their leadership identity. The Leadership Identity Development (LID) model includes a sequence of six stages an individual experiences as they develop their leadership identity: awareness, exploration/engagement, leader identified, leadership differentiated, generativity, and integration/synthesis (see Figure 1). The six stages of the developmental process were identified as leadership constructs (Komives et al., 2005).

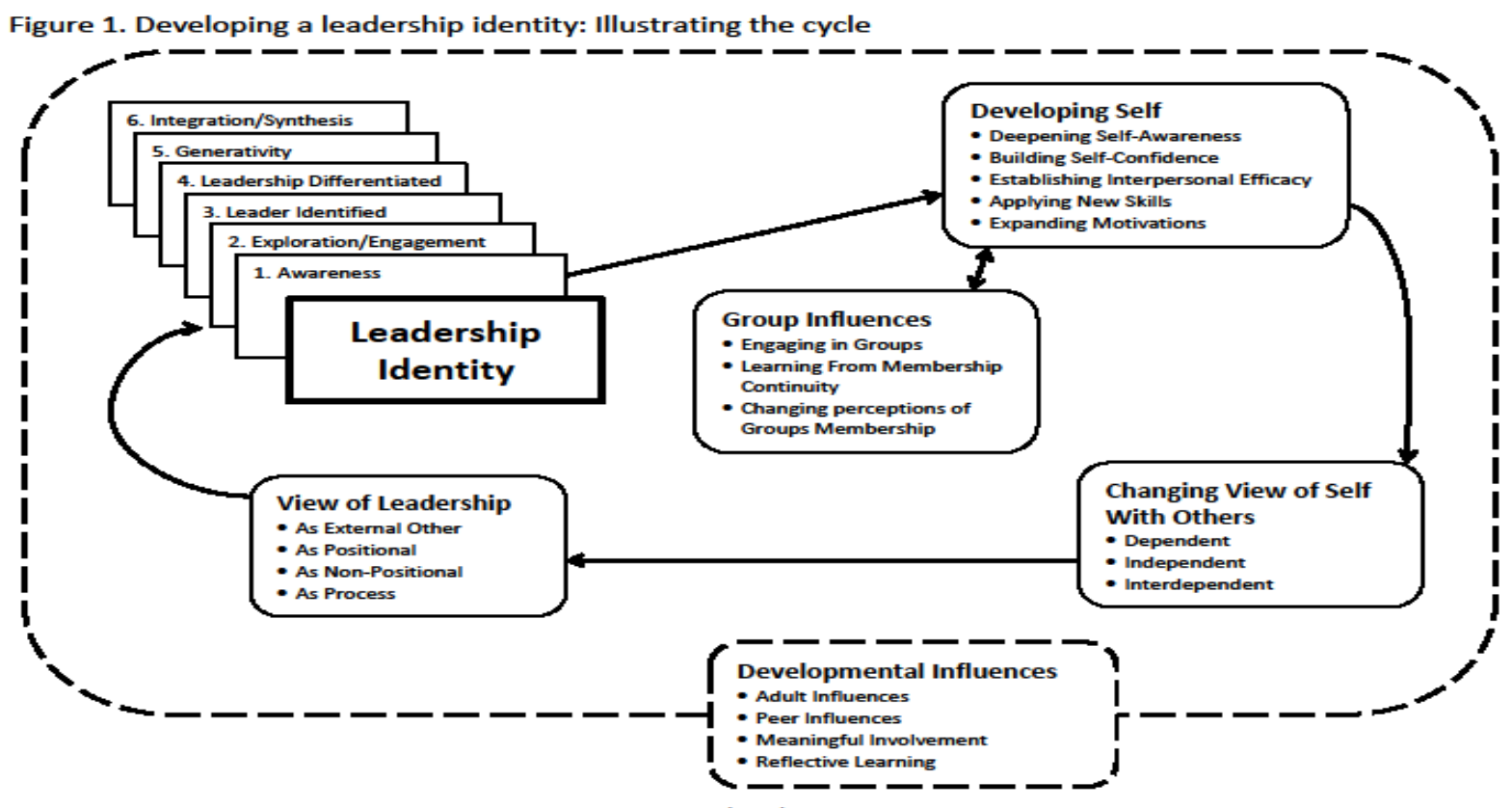

Komives, S. R., Owen, J. E., Longerbeam S. D., Mainella, F. C., \& Osteen, L. (2005). Developing a leadership identity: A grounded theory. Journal of College Student Development, 46(6), 593-611. doi: 10.1353/csd.2005.0061 
The awareness stage typically occurs during childhood and represents leadership as external and independent of the participant. The exploration/engagement stage is focused on the development of self-concept and self-confidence with influences by adults and peers. Stage three is leader identified suggesting that at this stage individuals identify a leader in a positional capacity responsible for group outcomes. At the leadership differentiated stage, individuals are moving beyond believing leadership is the responsibility of a positional leader to believing that leadership is the responsibility of all group members. Generativity or stage five is identified as individuals who begin accepting responsibility for the development of others into interdependent leaders. The integration/synthesis stage is characterized by active and continual engagement by the leader, striving for congruence and internal confidence, and value is placed on interdependent relationships.

Five organizational categories are identified as influencing the process of developing leadership identity (Komives et al., 2005):

1. Developmental influences

2. Developing self

3. Group influences

4. Changing view of self with others

5. Broadening view of leadership

A student's "growing awareness of self, increased self-confidence, establishment of personal efficacy, the application of new skills, increased motivation, and changed personal perceptions of group and individual roles" (Komives et al., 2005, p. 608) characterizes research for the LID model. Student's self-awareness and growth in leaders is a key element in their development potential as leaders. Shifts in development stages were a result of a broadening view of leadership based on students' broadening view of self with others and influenced by developmental influences, group influences, and development of self.

Stage four has been identified as a significant differentiation of the concept of leadership. A substantial subject-object shift (Komives et al., 2005) occurs between stages three and four when students' views of others change and views of self in relation to others changes. This is the period where students begin to see leadership as shared/participative even if they are in a positional role. Students also believe they can be a participant in the leadership process "without a positional title" and still be participating in leadership (Komives et al., 2005; Komives, Lucas, \& McMahon, 2006). There is potential for a "key crisis" to occur in stage three of the LID model. As students experience and explore their hierarchical understanding of leadership, a crisis may lead them to see leadership as more of a collaborative process and less of a focus on the positional leader.

Research using the LID model has surfaced in regard to examining students' mindsets of leadership (Wielkiewicz, Fischer, Stelzner, Overland, \& Sinner, 2012), specifically how students view leadership as hierarchical or systemic. Students with a more hierarchical view of leadership are likely to believe that outcomes of leadership are related to positional leaders. The systemic view is characterized by a belief that leadership in an organization should be the responsibility of every organizational member and open communication and adaptability correspond to greater 
success within the organization (Wielkiewicz et al., 2012). Komives et al. (2005) characterized students in stage three as having more hierarchical views and students in stage four identified more with systemic thinking views.

Wielkiewicz et al. (2012) examined the leadership identity of first-year college students at 22 institutions. This study evaluated students' leadership attitudes and beliefs and concluded incoming students show characteristics of stages 2 (exploration/engagement) and 3 (leader identified) of the LID model. Likewise, a qualitative study focused on the awareness stage of the LID model and found that students described their involvement in leadership differently based on position and non-positional roles (Shehane, Sturtevant, Moore, \& Dooley, 2012).

The LID model was developed to aid leadership educators in facilitating student leadership development (Komives et al., 2005). Determining where students stand in their leadership identity is important for leadership educators because it may serve as a "spring board" for designing curriculum and experiences for helping students develop leaders. Scholars have found leadership coursework experiences have a strong, significant, and positive impact on student learning and growth as a leader (Haber-Curran \& Tillapaugh, 2013; Lindsay, Foster, Jackson, \& Hassan, 2009; Thompson, 2013).

\section{Purpose and Objectives}

The purpose of this exploratory descriptive study was to examine the leadership mindsets or leadership thinking of undergraduate students completing leadership degrees (ALED and USAL-LED) in the Department of Agricultural Leadership, Education, and Communications at Texas A\&M University. Students complete four leadership courses during the course of their undergraduate studies that contain concepts related to hierarchical and systemic thinking. Through these courses, students begin to experience and learn about leadership as a process and not just a position. Table 1 illustrates the content taught in these courses with potential to influence students' leadership thinking.

Table 1

Leadership Courses at Texas A\&M University linked to Systemic vs. Hierarchical Thinking Course

\begin{tabular}{|c|c|c|}
\hline Number & Title & Leadership Concepts \\
\hline 200 level & Intro to Leadership & $\begin{array}{l}\text { Relational Leadership Model } \\
\text { Leadership Education vs. Leadership Development }\end{array}$ \\
\hline 300 level & $\begin{array}{l}\text { Personal } \\
\text { Leadership }\end{array}$ & $\begin{array}{l}\text { Social Change Model } \\
\text { LID Model }\end{array}$ \\
\hline 300 level & Leadership Theory & $\begin{array}{c}\text { Evolution of Theories: Progression from Great Man to } \\
\text { Transformational }\end{array}$ \\
\hline 400 level & Change & Individual, Group, and Organizational Change \\
\hline
\end{tabular}


It is hypothesized that students in a formal leadership degree with experiences that facilitate their growth and development will think more systemically as they progress through their undergraduate program. As students complete more formal leadership coursework, it is expected that they will think more systemically.

Existing research suggests leadership perceptions and attitudes may be affected by gender and experience (Komives et al., 2005; Wielkiewicz, 2000). Thus, this study seeks to expand on previous studies by evaluating the relationship between individual characteristics (gender and classification) and leadership thinking of leadership education students. Specifically, the study addressed the following objectives:

1. Describe leadership students' leadership mindsets in terms of hierarchical and systemic thinking.

2. Determine relationships between hierarchical and systemic leadership mindsets based on student characteristics of gender and academic classification.

\section{Methodology}

Survey research was the approach used in this study. The population for this study was undergraduate students majoring in leadership and enrolled in leadership courses at Texas A\&M University. There were a total of 1,034 students enrolled in leadership education courses when the data was collected. The accessible population was students enrolled in eight leadership courses in the spring 2013 semester. After removing students who were enrolled in multiple courses, the accessible population was 415 students. This sample, and the courses in which participants were enrolled, represented various stages of the degree program. A majority of students in this study were juniors and seniors; this is characteristic of the population as a majority of students enrolled in a leadership degree at Texas A\&M University are upperclassmen. Academic juniors have completed at minimum 60 college credit hours; seniors have completed 90 hours. This was a census study; however course selection was used as a slice in time sample (Oliver \& Hinkle, 1981) due to the variability in representativeness of the target population and participant demographics. The final dataset consisted of 313 students $(N=313)$ resulting in a response rate of $75.4 \%$.

A 36-item paper instrument used in this study consisted of the Leadership Attitudes and Beliefs Scale (LABS) (Wielkiewicz, 2002) and questions related to participants' personal characteristics. The LABS examines leadership thinking with two constructs: Hierarchical Thinking and Systemic Thinking. Each scale consisted of 14 items measured on a five-point summated scale: 1 (Strongly Disagree), 2 (Disagree), 3 (Neither Disagree nor Agree), 4 (Agree), and 5 (Strongly Agree). The hierarchical scale is representative of beliefs about leadership being more about a position and positional leaders being responsible for the success or failure of an organization. The systemic thinking scale is representative of beliefs that leadership is everyone's responsibility and open communication and adaptability provide a stronger chance for an organization's success (Wielkiewicz, 2000; Wielkiewicz, 2002). Convergent and discriminative validity of the scales have been established (Wielkiewicz, 2002). Other research studies have established the LABS as a valid tool for measuring college students' understanding and evaluation of leadership (Fischer, Overland, \& Adams, 2010; Thompson, 2006; 
Wielkiewicz, 2000; Wielkiewicz, 2002).

To address objective one of the study, descriptive statistics were implemented to describe leadership students' leadership mindsets using constructs of hierarchical and systemic thinking. Descriptive statistics reveal attitudes toward distinctive factors of groups who may be dissimilar (Agresti \& Finlay, 2009). The descriptive data included frequencies, percentages, mean scores, and standard deviations. Outcomes of descriptive statistics include arranging, summarizing, calculating, and describing a dataset.

The second objective of the study was to determine if significant differences existed between hierarchical and systemic thinking based on student characteristics (gender and classification). The researchers used independent sample t-tests (Field, 2009) to determine if significant differences existed among gender and hierarchical and systemic thinking. Significant differences between classification and hierarchical and systemic thinking were also assessed with t-tests due to two dominant groups of juniors and seniors.

The limitations of this study are the population as respondents were students enrolled in leadership courses in the Texas A\&M University. However, the results do offer those who teach college leadership courses insight into students' mindsets about their leadership attitudes and beliefs.

\section{Findings}

The first research objective of this study was to describe leadership students' leadership mindsets in terms of hierarchical and systemic thinking. Table 2 illustrates the descriptive statistics for hierarchical thinking from largest to smallest mean score with frequencies. The item with the highest mean for hierarchical thinking was "An organization should try to remain as stable as possible" $(M=3.95, S D=0.87)$. The next item was "A leader should take charge of the group" $(M=3.92, S D=0.80)$. The lowest mean for hierarchical thinking was "The most important members of an organization are its leaders" $(M=2.38, S D=1.07)$.

The descriptive statistics for Systemic Thinking are displayed in Table 3. "Individuals need to take initiative to help their organization accomplish its goals" was the item with the highest mean $(M=4.48, S D=0.67)$. The item with the lowest mean was "Environmental preservation should be a core value of every organization" $(M=3.09, S D=1.05)$. Twelve of the 14 items in the systemic thinking scale were above a mean score of four, indicating agreement. 
Table 2

- Descriptive Statistics for Hierarchical Thinking $(N=313)$

\begin{tabular}{|c|c|c|c|c|c|c|c|}
\hline \multirow[b]{2}{*}{ Item } & \multicolumn{5}{|c|}{ Responses \% $(f)$} & \multirow[b]{2}{*}{$M$} & \multirow[b]{2}{*}{$S D$} \\
\hline & $\begin{array}{l}\text { Strongly } \\
\text { Agree }\end{array}$ & Agree & $\begin{array}{l}\text { Neither } \\
\text { Agree nor } \\
\text { Disagree }\end{array}$ & Disagree & $\begin{array}{l}\text { Strongly } \\
\text { Disagree }\end{array}$ & & \\
\hline An organization should try to & & & & & & & \\
\hline A remain as stable as nossible & $25.2(79)$ & $52.7(165)$ & $14.7(46)$ & $6.1(19)$ & $1.3(4)$ & 3.95 & 0.87 \\
\hline the group. & $21.1(66)$ & $55.9(175)$ & $17.6(55)$ & $4.8(15)$ & $0.6(2)$ & 3.92 & 0.79 \\
\hline $\begin{array}{l}\text { Leaders are responsible for the } \\
\text { security of organization } \\
\text { members. }\end{array}$ & $16.6(52)$ & $53.7(168)$ & $26.5(83)$ & $2.9(9)$ & $0.3(1)$ & 3.83 & 0.74 \\
\hline $\begin{array}{l}\text { The responsibility for taking } \\
\text { risks lies with the leaders of } \\
\text { an organization. }\end{array}$ & $13.4(42)$ & $54.6(171)$ & $19.5(61)$ & $11.8(37)$ & $0.6(2)$ & 3.68 & 0.87 \\
\hline $\begin{array}{l}\text { The main tasks of a leader are } \\
\text { to make and then } \\
\text { communicate decisions. }\end{array}$ & $14.1(44)$ & $48.6(152)$ & $17.9(56)$ & $17.6(55)$ & $1.9(6)$ & 3.55 & 1.00 \\
\hline $\begin{array}{l}\text { Members should be } \\
\text { completely loyal to the } \\
\text { designated leaders of an } \\
\text { organization. }\end{array}$ & $12.8(40)$ & 36.7 (115) & 37.7 (118) & $11.5(36)$ & $1.3(4)$ & 3.48 & 0.90 \\
\hline $\begin{array}{l}\text { The main task of a leader is to } \\
\text { make important decisions } \\
\text { for an organization. } \\
\text { A leader must maintain tight }\end{array}$ & $13.1(41)$ & $36.1(113)$ & $29.7(93)$ & $18.8(59)$ & $2.2(7)$ & 3.39 & 1.01 \\
\hline A leantrol of the organization. & $9.9(31)$ & $32.6(102)$ & $36.7(115)$ & $19.2(60)$ & $1.6(5)$ & 3.30 & 0.94 \\
\hline $\begin{array}{l}\text { group or organization. } \\
\text { Positional leađers deserve }\end{array}$ & $9.3(29)$ & $35.1(110)$ & $32.9(103)$ & $20.8(65)$ & $1.9(6)$ & 3.29 & 0.96 \\
\hline $\begin{array}{l}\text { credit for the success of an } \\
\text { organization. }\end{array}$ & $5.1(16)$ & $27.8(87)$ & $39.9(125)$ & $22.0(69)$ & $5.1(16)$ & 3.06 & 0.95 \\
\hline $\begin{array}{l}\text { When an organization is in } \\
\text { danger of failure, new } \\
\text { leaders are needed to fix its } \\
\text { problems. } \\
\text { It is important that a single }\end{array}$ & $5.8(18)$ & $23.4(73)$ & $40.3(126)$ & $26.2(82)$ & $4.5(14)$ & 3.00 & 0.95 \\
\hline $\begin{array}{l}\text { A leader emerges in a group. } \\
\text { A leader should mantarn }\end{array}$ & $6.1(19)$ & $15.7(49)$ & 37.4 (117) & $37.1(116)$ & $3.8(12)$ & 2.83 & 0.95 \\
\hline $\begin{array}{l}\text { complete authority. } \\
\text { The most important members }\end{array}$ & $5.8(18)$ & $21.4(67)$ & $28.8(90)$ & $36.4(114)$ & $7.7(24)$ & 2.81 & 1.04 \\
\hline $\begin{array}{l}\text { of an organization are its } \\
\text { leaders. }\end{array}$ & $5.8(18)$ & $9.6(30)$ & $20.4(64)$ & $45.4(142)$ & $18.8(59)$ & 2.38 & 1.07 \\
\hline
\end{tabular}


Table 3

Descriptive Statistics for Systemic Thinking $(N=313)$

\begin{tabular}{|c|c|c|c|c|c|c|c|}
\hline \multirow[b]{3}{*}{ Item } & \multicolumn{5}{|c|}{ Responses \% $(f)$} & \multirow[b]{3}{*}{$M$} & \multirow[b]{3}{*}{$S D$} \\
\hline & & & Neither & & & & \\
\hline & $\begin{array}{l}\text { Strongly } \\
\text { Agree }\end{array}$ & Agree & $\begin{array}{c}\text { Agree nor } \\
\text { Disagree }\end{array}$ & Disagree & $\begin{array}{l}\text { Strongly } \\
\text { Disagree }\end{array}$ & & \\
\hline $\begin{array}{l}\text { Individuals need to take initiative } \\
\text { to help their organization } \\
\text { accomplish its goals. }\end{array}$ & $53.4(167)$ & $43.5(136)$ & $1.9(6)$ & $0.0(0)$ & $1.3(4)$ & 4.48 & 0.66 \\
\hline $\begin{array}{l}\text { An organization needs flexibility } \\
\text { in order to adapt to a rapidly } \\
\text { changing world. }\end{array}$ & $47.1(147)$ & $48.6(152)$ & $2.9(9)$ & $1.0(3)$ & $0.6(2)$ & 4.41 & 0.65 \\
\hline $\begin{array}{l}\text { Leadership should encourage } \\
\text { innovation. }\end{array}$ & $45.0(141)$ & $50.8(159)$ & $3.8(12)$ & $0.0(0)$ & $0.3(1)$ & 4.40 & 0.60 \\
\hline $\begin{array}{l}\text { Organizations must be ready to } \\
\text { adapt to changes that occur } \\
\text { outside the organization. }\end{array}$ & $44.1(138)$ & $52.4(164)$ & $2.9(9)$ & $0.0(0)$ & $0.6(2)$ & 4.39 & 0.61 \\
\hline $\begin{array}{l}\text { Everyone in an organization is } \\
\text { responsible for accomplishing } \\
\text { organizational goals. }\end{array}$ & 44.4 (139) & $50.5(158)$ & $4.2(13)$ & $0.6(2)$ & $0.3(1)$ & 4.38 & 0.63 \\
\hline $\begin{array}{l}\text { Effective leadership seeks out } \\
\text { resources needed to adapt to a } \\
\text { changing world. }\end{array}$ & 45.4 (124) & $47.3(148)$ & $6.7(21)$ & $0.3(1)$ & $0.3(1)$ & 4.38 & 0.65 \\
\hline $\begin{array}{l}\text { Leadership processes involve the } \\
\text { participation of all organization } \\
\text { members. }\end{array}$ & $40.3(126)$ & $45.0(141)$ & $10.5(33)$ & $3.8(12)$ & $0.3(1)$ & 4.21 & 0.79 \\
\hline $\begin{array}{l}\text { An effective organization } \\
\text { develops its human resources. }\end{array}$ & 30.7 (96) & $60.7(190)$ & $7.7(24)$ & $0.6(2)$ & $0.3(1)$ & 4.21 & 0.63 \\
\hline $\begin{array}{l}\text { Good leadership requires that } \\
\text { ethical issues have high priority. }\end{array}$ & 35.5 (111) & $51.4(161)$ & $11.5(36)$ & $1.3(4)$ & $0.3(1)$ & 4.20 & 0.71 \\
\hline $\begin{array}{l}\text { Organizational actions should } \\
\text { improve life for future } \\
\text { generations. }\end{array}$ & $33.2(104)$ & $51.4(161)$ & $13.7(43)$ & $1.3(4)$ & $0.3(1)$ & 4.16 & 0.72 \\
\hline $\begin{array}{l}\text { Successful organizations make } \\
\text { continuous learning their } \\
\text { highest priority. }\end{array}$ & $32.6(102)$ & $49.2(154)$ & $15.3(48)$ & $2.6(8)$ & $0.3(1)$ & 4.11 & 0.77 \\
\hline $\begin{array}{l}\text { Leadership activities should foster } \\
\text { discussions about the future. }\end{array}$ & $24.6(77)$ & $60.1(188)$ & $14.1(44)$ & $1.0(3)$ & $0.3(1)$ & 4.08 & 0.67 \\
\hline $\begin{array}{l}\text { Anticipating the future is one of } \\
\text { the most important roles of } \\
\text { leadership processes. }\end{array}$ & $16.3(51)$ & $58.1(182)$ & $20.1(63)$ & $4.8(15)$ & $0.6(2)$ & 3.85 & 0.77 \\
\hline $\begin{array}{l}\text { Environmental preservation } \\
\text { should be a core value of every } \\
\text { organization. }\end{array}$ & $8.6(27)$ & $27.2(85)$ & $35.8(112)$ & $21.4(67)$ & $7.0(22)$ & 3.09 & 1.05 \\
\hline
\end{tabular}


Scores were calculated for each thinking scale. Scores range from 14 (low) to 70 (high). The majority of the participants scored below the midline threshold (56) on the hierarchical scale and above the threshold on the systemic scale. Means and standard deviations were calculated for each thinking scale based on participant's gender and classification (see Table 4). Males had the highest mean score for hierarchical thinking $(M=47.81, S D=7.04)$, and females had the highest mean score for systemic thinking $(M=58.83, S D=4.86)$. Seniors averaged the lowest in hierarchical $(M=45.58, S D=7.19)$ and the highest in systemic thinking $(M=59.00, S D=4.79)$.

Table 4

- Descriptive Statistics for Summative Thinking Scales by Characteristic $(N=313)$

\begin{tabular}{|c|c|c|c|c|c|}
\hline \multirow[b]{2}{*}{ Characteristic } & \multirow[b]{2}{*}{$n$} & \multicolumn{2}{|c|}{ Hierarchical Thinking } & \multicolumn{2}{|c|}{ Systemic Thinking } \\
\hline & & $M$ & $S D$ & $M$ & $S D$ \\
\hline \multicolumn{6}{|l|}{ Gender } \\
\hline Males & 183 & 47.81 & 7.04 & 57.98 & 6.10 \\
\hline Females & 130 & 44.59 & 7.89 & 58.83 & 4.86 \\
\hline \multicolumn{6}{|l|}{ Classification } \\
\hline Freshmen & 10 & 46.50 & 8.75 & 57.50 & 6.85 \\
\hline Sophomores & 46 & 47.17 & 8.86 & 57.70 & 5.80 \\
\hline Juniors & 106 & 47.44 & 7.27 & 57.75 & 6.44 \\
\hline Seniors & 151 & 45.58 & 7.19 & 59.00 & 4.79 \\
\hline
\end{tabular}

Note: Score ranges are from 14 (low) to 70 (high).

To address the second research objective, inferential statistics were used to investigate the differences between gender and the two prominent classification groups for the two thinking scales: juniors and seniors. In Table 5, the researchers compared the means of males and females using independent samples $t$-test with alpha level set a priori at $.05(\alpha=.05)$. There was a significant difference in gender for hierarchical thinking between males $(M=47.81, S D=7.04)$ and females $(M=44.59, S D=7.89)$; the effect size was small $r=.21$. There was not a significant difference between males and females for systemic thinking, $t(311)=-1.315, p=.190$.

Table 5

- Independent t-tests with Thinking Scales and Gender $(N=313)$

\begin{tabular}{llccccc} 
Thinking Scale & Gender & $N$ & $M$ & $S D$ & $t$ & $p$ \\
\hline Hierarchical & Males & 183 & 47.81 & 7.04 & $3.792 *$ & .001 \\
\multirow{3}{*}{ Systemic } & Females & 130 & 44.59 & 7.89 & & \\
& Males & 183 & 57.98 & 6.10 & -1.315 & .190 \\
& Females & 130 & 58.83 & 4.86 & &
\end{tabular}

Note: $* p<.05$ 
The majority of the participants were juniors $(n=106)$ and seniors $(n=151)$. In Table 6 the findings are displayed for the independent samples $t$-tests for juniors and seniors on the thinking scales. There was a significant difference, $t(255)=2.033, p=.043$, between groups for hierarchical thinking. The effect size was small $r=.13$. Systemic thinking scales were not significantly different between juniors and seniors.

Table 6

-Independent t-tests with Thinking Scales and Upperclassmen $(N=257)$

\begin{tabular}{llccccc} 
Thinking Scale & Classification & $N$ & $M$ & $S D$ & $t$ & $p$ \\
\hline Hierarchical & Juniors & 106 & 47.44 & 7.27 & $2.033^{*}$ & .043 \\
\multirow{3}{*}{ Systemic } & Seniors & 151 & 45.58 & 7.19 & & \\
& Juniors & 106 & 57.75 & 6.44 & -1.790 & .075 \\
& Seniors & 151 & 59.00 & 4.79 & & \\
\hline
\end{tabular}

Note: $* p<.05$

\section{Conclusions and Implications}

In this study males were significantly higher than females in hierarchical thinking, which is congruent with past research using the LABS scale (Wielkiewicz et al., 2012). There was no significant difference in gender for systemic thinking, which is different from previous findings (Wielkiewicz et al., 2012). However, previous research was focused on students enrolled in introductory courses. For this specific study, the difference between genders may become nonsignificant as time progresses with the influence of leadership curriculum.

Komives et al. (2005) found students in Stage 3 of the LID Model were characterized by hierarchical thinking and students in Stage 4 were more systemic thinkers. In this study, seniors scored significantly lower in hierarchical thinking. The finding implies the more formal leadership coursework a student completes the more their mindset of leadership may evolve from a positional perspective to a comprehensive view. By the spring semester, seniors have completed three required leadership courses, which include an introductory course, a personal leadership course, and a leadership theory course. Most seniors are enrolled in their last three courses, which include ethics, leading change, and their capstone seminar. Additionally, seniors may have completed an elective leadership course focused on teams, learning organizations, volunteering, culture, or training. With the influence of these courses, senior leadership students have moved to the leadership differentiated stage, beginning to identify leadership as a collaborative process between organizational members, which is characteristic of systemic thinking.

Juniors, on the other hand, scored significantly higher in hierarchical thinking. Students in the junior classification may just be beginning their leadership coursework. They are more than likely to have completed the introductory course and are currently enrolled in either personal leadership or leadership theory. At this point, juniors appear to be in stage 3 of the LID Model-leader identified. At this stage, individuals identify leaders by position, which is congruent with the hierarchical thinking scale. And, although not significant, juniors did average 
lower than seniors in systemic thinking. This leads the researchers to believe formal coursework has an impact on students' leadership growth and development, as determined by Thompson (2013).

\section{Recommendations}

This study provides baseline data for examining the leadership mindsets of current students in one leadership degree program at a single university. It is recommended that this study be replicated in other leadership degree programs as a way to evaluate the curriculum being offered and determine if leadership coursework is having the effect intended by the stakeholders of that program. Additionally, researchers should compare students majoring in leadership and students in other disciplines. A comparison study would indicate if leadership education versus other disciplines impact students' leadership thinking.

Further research should examine specific leadership experiences and the relationships between them and the thinking scales. This study did not differentiate between the knowledge students gained through formal coursework and the knowledge gained from other leadership developmental experiences while in college. It is important to understand if specific experiences in courses such as high-impact experiences have an influence on students' thinking in regard to leadership. The study could also reveal if leadership thinking is affected by the continued growth and development of students in general or the influence of leadership education.

Finally, it is recommended that a longitudinal study be conducted following one random sample of students in a leadership program throughout their undergraduate years to examine effects of their experiences and their change in thinking at different stages. This study could identify turning points that promote students' change in thinking in regard to leadership.

Based on the results of this study, the researchers recommend that college and universities who offer degree programs and formal coursework in leadership be purposeful in creating opportunities for students to grow and develop into systemic thinkers. Komives et al. (2009) offered suggestions to leadership educators to apply the LID model to leadership education practice. As leadership educators offer intentional ways for students to develop systemic views of leadership, students will be better prepared to demonstrate leadership and make a difference in their future career endeavors.

\section{References}

Andenoro, A. C., Allen, S. J., Haber-Curran, P., Jenkins, D. M., Sowcik, M., Dugan, J. P., \& Osteen, L. (2013). National leadership education research agenda 2013-2018: Providing strategic direction for the field of leadership education. Retrieved from Association of Leadership Educators website: http://leadershipeducators.org/ResearchAgenda.

Agresti, A., \& Finlay, B. (2009). Statistical methods for the social sciences (4th ed.). Upper Saddle River, NJ: Prentice Hall. 
Allen, K. E., Stelzner, S. P., \& Wielkiewicz, R. M. (1998). The ecology of leadership: Adapting to the challenges of a changing world. Journal of Leadership Studies, 5(2), 62-82.

Astin, A. W., \& Astin, H. S. (2000). Leadership reconsidered: Engaging higher education in social change. Michigan: W. K. Kellogg Foundation.

Bass, B. M. (2008). The Bass handbook of leadership: Theory, research, and managerial applications (4th ed.). New York: The Free Press.

Black, A. M., \& Earnest, G. W. (2009). Measuring the outcomes of leadership development programs. Journal of Leadership \& Organizational Studies, 16(2), 184-196. doi: $10.1177 / 1548051809339193$

Blackwell, C., Cummins, R., Townsend, C. D., \& Cummings, S. (2007). Assessing perceived student leadership skill development in an academic leadership development program. Journal of Leadership Education, 6(1), 39-58.

Brungardt, C., Greenleaf, J. , Brungardt, C., \& Arensdorf, J. (2006). Majoring in leadership: A review of undergraduate leadership degree programs. Journal of Leadership Education, $5(1), 4-25$.

Crawford, P., Lang, S., Fink, W., Dalton, R., \& Fielitz, L. (2011). Comparative analysis of soft skills: What is important for new graduates? Washington, DC: Association of Public and Land-grant Universities.

Field, A. (2009). Discovering statistics using SPSS (3rd ed.). Thousand Oaks, CA: Sage.

Fischer, D. V., Overland, M., \& Adams, L. (2010). Leadership attitudes and beliefs of incoming first-year college students. Journal of Leadership Education, 9(1), 1-16.

Goertzen, B. J. (2009). Assessment in academic based leadership education programs. Journal of leadership Education, 8(1), 148-162.

Greenwald, R. (2010, December 5). Today's students need leadership training like never before. Chronicle of Higher Education. Retrieved from http://www.chronicle.com

Haber, P. (2012). Perceptions of leadership: An examination of college students' understandings of the concept of leadership. Journal of Leadership Education, 11(2), 26-51.

Haber-Curran, P., \& Tillapaugh, D. (2013). Leadership learning through student-centered and inquiry-focused approaches to teaching adaptive leadership. Journal of Leadership Education, 12(1), 92-116. 
Komives, S. R., Longerbeam, S. D., Mainella, F., Osteen, L., Owen, J. E., \& Wagner, W. (2009). Leadership identity development: Challenges in applying a developmental model. Journal of Leadership Education, 8(1), 11-47.

Komives, S. R., Lucas, N., \& McMahon, T. R. (2006). Exploring leadership: For college students who want to make a difference (3rd ed.). San Francisco CA: Jossey-Bass.

Komives, S. R., Owen, J. E., Longerbeam, S. D. Mainella, F. C., \& Osteen, L. (2005). Developing a leadership identity: A grounded theory. Journal of College Student Development, 46(6), 593-611. doi: 10.1353/csd.2005.0061

Lindsay, D. R., Foster, C. A., Jackson, R. J., \& Hassan, A. M. (2009). Leadership education and assessment: A developmental approach. Journal of Leadership Education, 8(1), 163-176.

Middlebrooks, A., \& Allen, S. (2009). Editor's introduction: The education of leadership. Journal of Leadership Education, 8(1), viii-xxii.

National Association of Colleges and Employers (2013, October 2). Job outlook: The candidate skills/qualities employers want. Retrieved from https://www.naceweb.org/s10022013/joboutlook-skills-quality.aspx

Northouse, P. G. (2013). Leadership: Theory and practice (6th ed.). Thousand Oaks, CA: Sage

Oliver, J. D., \& Hinkle, D. E. (1981). Selecting statistical procedures for agricultural education research. Paper presented at the 8th annual National Agricultural Education Research Meeting, Atlanta, GA.

Shehane, M. R., Sturtevant, K. A., Moore, L. L., \& Dooley, K. E. (2012). First-year student perceptions related to leadership awareness and influences. Journal of Leadership Education, 11(1), 140-156.

Thompson, M. D. (2013). Student leadership development and orientation: Contributing resources within the liberal arts. American Journal of Education Research, 1(1), 1-6.

Wielkiewicz, R. M. (2000). The Leadership Attitudes and Beliefs Scale: An instrument for evaluating college students' thinking about leadership and organizations. Journal of College Student Development, 41(3), 335-346.

Wielkiewicz, R. M. (2002). Validity of the Leadership Attitudes and Beliefs Scale: Relationships with personality, communal orientation, and social desirability. Journal of College Student Development, 43(1), 108-118.

Wielkiewicz, R. M., Fischer, D. V., Overland, M., \& Sinner, A. M. (2012). Leadership attitudes and beliefs of incoming first year college students: A multi-institutional study of gender differences. Journal of Leadership Education, 11(2), 1-25. 


\section{Author Biographies}

Sarah Ho is an academic advisor for the Agricultural Leadership and Development degree program at Texas A\&M University. Her research interests include leadership pedagogy, academic advising, and high impact experiences. Sarah received her B.S. in Human Resource Development and M.S. in Higher Educational Administration, both from Texas A\&M University. She is currently working on her doctoral degree in the Department of Agricultural Leadership, Education, and Communications.

Summer F. Odom is an Assistant Professor in the Department of Agricultural Leadership, Education, \& Communications (ALEC) at Texas A\&M University. She teaches courses in personal and professional leadership. Dr. Odom received her Ph.D. in Human Resource Development in May 2011. Some of her research interests include programmatic assessment and evaluation of leadership programs and the psychological development of leaders, followers, and learners. 